Paulina Nicko-Stępień

Papieski Wydział Teologiczny

Wrocław

\title{
Źródła dla komentarza tekstowego Nowego Testamentu w tłumaczeniu Jakuba Wujka z roku 1593. Studium Dz 2, 14-36
}

Celem artykułu jest wskazanie źródeł dla komentarza tekstowego Nowego Testamentu w tłumaczeniu Jakuba Wujka z 1593 r. Zagadnienie zostanie przedstawione na przykładzie $\mathrm{Dz} 2,14-36$. Jezuita w pracy translatorskiej posłużył się angielskim Nowym Testamentem z Rheims z 1582 r. i łacińskim komentarzem Roberta Bellarmina pt. Disputationes Christianae Fidei. Kwestia źródeł dla Nowego Testamentu w tłumaczeniu Wujka była do tej pory niemal zupełnie niezbadana albo rozpoznana błędnie. Tymczasem zestawienie komentarza Wujkowego z komentarzami z dzieła Bellarmina i Nowym Testamentem z Rheims doprowadziło do zaskakujących rezultatów: Jakub Wujek, jeden z najwybitniejszych tłumaczy biblijnych XVI w., najprawdopodobniej znał język angielski, a jego komentarz tekstowy do Nowego Testamentu z 1593 r. stanowi kompilację tekstów dwóch wyżej wymienionych dzieł. To oznacza, że jako komentator Wujek był w ogromnym stopniu odtwórczy i zależny od źródeł, i nie korzystał bezpośrednio z dzieł Ojców Kościoła, ale cytował ich fragmenty z gotowych już kompendiów.

The purpose of the study is to indicate the sources for a textual commentary to the New Testament in Jakub Wujek's translation of 1593. The problem is presented on the example of the Acts 2:14-36. The Jesuit in his translatory work used the English Rheims New Testament of 1582, and Robert Bellarmine's Latin commentary entitled Disputationes Christianae Fidei. The question of sources for the New Testament in Jakub Wujek's translation has been almost completely unexplored or explored incorrectly. A comparative analysis of Wujek's commentary with that of Bellarmine's and of the 
Rheims New Testament has led to surprising conclusions: that Jakub Wujek, one of the most outstanding Bible translators in the sixteenth century, probably knew English, and his textual commentary to the New Testament of 1593 is a compilation of the two abovementioned texts. This means that as a Bible commentator Wujek was imitative and dependent on secondary sources, as he did not use texts by Church Fathers, but relied on quotations from their writings he found in other compendia.

Słowa kluczowe: Jakub Wujek, reformacja, renesans, Biblia, Robert Bellarmin, Rheims, prymat Piotrowy

Ke ywo rds: Jakub Wujek, Reformation, Renaissance, Bible, Robert Bellarmine, Rheims, Peter's primacy

Pierwsze wydanie Nowego Testamentu w tłumaczeniu Jakuba Wujka pochodzi z roku $1593^{1}$ i w największym stopniu odzwierciedla warsztat tłumacza. Tylko ta edycja zawiera bowiem teksty biblijne w takiej postaci, w jakiej je pozostawił Wujek wraz z komentarzami tekstowymi. Druga edycja Nowego Testamentu, z roku $1594^{2}$, ma nieznacznie tylko zmieniony tekst biblijny (Wujek poprawił pierwszą wersję na podstawie Wulgaty Syksto-Klementyńskiej), jednak nie zawiera już komentarzy tekstowych, co sam tłumacz uzasadnił następująco:

Po wydaniu Nowego Testamentu przez mię przeszłego roku z łacińskiego i z greckiego języka na polski przełożonego z przydanim annotacyj, Czytelniku Miły, umyśliłem był zaraz wydać tenże tekst Nowego Testamentu bez żadnych annotacyj, na mniejsze modum, jako zowią, dla tych, którzy by abo więtszego Testamentu kupić nie przemogli, abo sam goły tekst bez annotacyj radzi mieli ${ }^{3}$.

${ }^{1}$ Nowy Testament Pana naszego IESVSA CHRISTVSA. Z nowu z Laćinskiego y $z$ Gręckiego na Polskie wiernie a szczyrze przetożony: y Argumentami abo Summariuszami każdych Kśiag / y Rozdźiatow / y Annotacyami po brzegach obiaśniony. Przydane sa Nauki y Przestrogi mato nie za każdym Rozdźiatem: Porownanie Ewangelistow SS. Dźieie y drogi rozmaite Piotra y Pawta S. y Regestr rzeczy gtownieyszych na końcu. Przez D. IAKVBA WVYKA, Theologa Societatis IESV. Z dozwoleniem Starszych. Pod rozsadek Kośćiota S. Powszechnego Rzymskiego wszytko niech podlęże, Kraków: A. Piotrkowczyk, 1593, 4º, BO, sygn. XVI.Qu.3065.

${ }^{2}$ Nowy Testament Pana naszego IESVSA CHRISTUSA. $Z$ nowu z Laćińskiego y z Grackiego na Polskie wiernie a szczyrze przetożony. Przez D. IAKVBA WVYKA Theologa Societatis IESV. Z dozwoleniem Starszych. Pod rozsadek Kościota S. Powszechnego Rzymskiego wszytko niech podlęże, Kraków: A. Piotrkowczyk, 1594, 8², BO, sygn. XVI.O.665.

3 J. Wujek, Przedmowa do czytelnika, w: Nowy Testament w przektadzie ks. dr Jakuba Wuika T.J. z roku 1593, red. W. Smereka, Kraków 1966, s. LXXIII. 
Trzecia edycja, z roku $1599^{4}$, zawierająca zarówno Stary, jak i Nowy Testament, została wydana dwa lata po śmierci Wujka i przez wielu badaczy nazywana jest „Biblią niby Wujkową”, teksty tego wydania zostały bowiem $\mathrm{w}$ znacznym stopniu zmienione przez komisję cenzorów i dostosowane do Wulgaty, przez co piękno Wujkowego tłumaczenia niestety straciło na wartości. Wybór pierwszej edycji jest ważny z jeszcze jednego powodu - w przedmowie do tego wydania Wujek jasno i wyraźnie podał źródła, z jakich korzystał podczas tłumaczenia. Swój komentarz marginalny oparł na Wulgacie Lowańskiej ${ }^{6}$, natomiast przy pisaniu komentarza tekstowego sięgał do angielskiego wydania Nowego Testamentu z Rheims z roku $1582^{7}$ oraz komentarza Roberta Bellarmina pt. Disputationes de Controversiis Christianae Fidei ${ }^{8}$. Artykuł stanowi więc próbę odpowiedzi na następujące pytania: czy Wujek sam znał angielski, czy może miał kogoś do pomocy przy tłumaczeniu NTR 1582? W jaki sposób korzystał ze źródeł przy pisaniu komentarza tekstowego? Czy i tym razem

${ }^{4}$ BIBLIA TO IEST KSIEGI STAREGO Y NOWEGO TESTAMNETV WEDEVG EACINSKIEGO przektadu starego, w kośćiele powszechnym przyiętego, na Polski ięzyk z nowu z pilnośćia przetożone, Z DOKEADANIEM TEXTV ZYDOWSKIEGO y Greckiego, y z wyktadem Katholickim, trudnieyszych mieysc do obrony Wiary swietey powszechney przeciw kacerztwóm tych czasów nalezacych: PRZEZ D. IAKVBA WVYKA Z WAGROWCA, THEOLOGA SOCIETATIS IESV. Z DOZWOLENIEM STOLICE APOSTOLSKIEY, a naktadem Iego M. Księdza Arcybiskupa Gnieźnieńskiego, etć. wydane, Kraków: Druk. Łazarzowa, nakł. S. Karnkowski, 1599, 2, BUWr, sygn. 437771, BO, sygn. XVI.F.4289.

${ }^{5}$ Takiego określenia używa np. J. Gołąb; zob. idem, O ttumaczeniu Nowego Testamentu przez Jakóba Wujka, Warszawa 1906, s. 21.

${ }^{6}$ Biblia sacra: Quid in hacediotione a Theologis Louaniensibus praesitum sit, paolo post indicatur, Antverpiae, K. Plantinus, 1574, $8^{\circ}$, Biblioteka Kapitulna we Wrocławiu, sygn. I 24.O. Wpływ Wulgaty Lowańskiej na warsztat Wujka pokazałam w artykule: Wulgata Lowanska a Nowy Testament w przektadzie ks. Jakuba Wujka z roku 1593. Studium Mt 16, 13-20, OiRwP, 59, 2015, s. 47-66.

7 The NEVV TESTAMENT OF IESVS CHRIST, TRANSLATED FAITHFVLLY INTO ENGLISH out of the authentical Latin, according the best corrected copies of the same, diligently conferred vvith the Greeke and other editions in divers languages: Vvith ARGVMENTS of bookes and chapters, ANNOTATIONS, and other necessarie helpes, for the better vnderstanding o the text, and specially for the discoverie of the CORRVPTIONS of divers late translations, and for cleering the CONTROVERSIES in religion, of these daies: IN THE ENGLISH COLLEGE OF RHEMES, Rhemes: I. Fogny, 1582, Princeton Theological Seminary Library, sygn. 3.25.13.40-2/6.

${ }^{8}$ Disputationes Roberti Bellarmini Politiani, Societatis Iesv, De Controversiis Christianae Fidei, Adversus huius temporis Haereticos: Tribus Tomis comprehensae. Primi Tomi. Tertia Controversia Generalis, De Summo Pontifice, Ingolstadii: Sartorius, 1587. 
był równie mocno zależny od tekstów źródłowych, jak w przypadku not marginalnych, które $\mathrm{w}$ ponad 90 procentach zaczerpną $\mathrm{z}$ Wulgaty Lowańskiej? Zagadnienie zasługuje na uwagę, zwłaszcza że jest ono zupełnie nieznane $\mathrm{w}$ polskich studiach nad staropolskimi przekładami biblijnymi. Do tej pory nikt $\mathrm{z}$ badaczy Biblii Wujka nie podjął studiów nad źródłami komentarza tekstowego. Niektórzy wprawdzie mieli świadomość tematu, ale nie zainteresowali się nim bądź też ograniczyli się jedynie do stwierdzenia, że „Wujek korzystał z dzieł Ojców Kościoła”, nie sprawdziwszy jednak, czy rzeczywiście tak było.

Komentarz tekstowy w NTW 1593 i źródła do ni ego

Charakter komentarza tekstowego opisał sam Wujek w Przedmowie do czytelnika:

Drugie annotacyje dłuższe, którem nazwał Nauki i przestrogi, są mało nie po każdym rozdziale położone, które oprócz wykładów niektórych miejsc trudniejszych, osobliwie te miejsca pokazują i krótko wykładają, które abo heretycy psują i fałszują naciągając ich za wymysły swemi, abo które wiarę naszę katolicką przeciwko ich błędom znacznie potwierdzają. A te annotacyje częścią z samego Pisma św., częścią też z wykładu starych onych Ojców i Doktorów kościelnych, których imiona mało nie wszędy są położone, częścią też i z nowych, a na imię z Bellarmina i z annotacyj Nowego Testamentu angielskiego od katolików w Remsie, we Francyjej roku Pańskiego 1582 wydanego, są zebrane, aby się pokazało, iż wszystko Pismo św., wszędy jest za katolikami przeciwko tym, którzy się rzekomo samego pisma trzymają ${ }^{10}$.

Nauki i przestrogi był to zatem dłuższy komentarz, umieszczany przez jezuitę z Wągrowca niemalże po każdym rozdziale danej księgi Nowego Testamentu, poruszający ważne i trudne kwestie zawarte w konkretnym fragmencie biblijnym. Miał on charakter teologiczny i jednocześnie apologetyczny. W tym komentarzu tłumacz bronił wiary katolickiej, wykazując błędy w doktrynie innowierców. Teksty Nauk i przestróg przeznaczono dla czytelnika bardziej wykształconego, obeznanego z literaturą patrystyczną i znającego aktualne problemy katolicyzmu polskiego. Dzieła Ojców Kościoła nie były jednak cytowane bezpośrednio, Wujek poszczególne fragmenty zaczerpnął bowiem z dwóch gotowych komentarzy: NTR 1582 i RB.

\footnotetext{
9 Tak czyni choćby D. Bieńkowska; eadem, Jak Jakub Wujek Pismo Święte na język polski przektadat ( $O$ warsztacie ttumacza i technice przez niego stosowanej), „Bobolanum", 9, 1998, s. 28.

${ }^{10}$ J. Wujek, Przedmowa do czytelnika, s. LXX.
} 
Trzytomowe dzieło Roberta Bellarmina zatytułowane Disputationes de Controversiis Christianae Fidei adversus huius temporis haereticos powstawało w latach 1581-1593 w Rzymie, a zostało wydane w Ingolstadt. Był to jeden z najobszerniejszych i najbardziej znanych w dobie reformacji komentarzy broniących wiary katolickiej. Katechizm ten poruszał kwestie natury dogmatycznej, wówczas najbardziej atakowane, odnosił się do tematu papiestwa i prymatu Piotrowego (t. 1). Początki kolejnego dzieła wykorzystywanego przez Jakuba Wujka podczas pracy translatorskiej - Nowego Testamentu z Rheims - związane są z Uniwersytetem w Douai, który stanowił centrum angielskiego katolicyzmu. W obliczu zagrożenia reformacją protestancką pojawiła się nagląca potrzeba m.in. nowego tłumaczenia Biblii, które uwzględniałoby ducha epoki. Zadania tego podjął się Gregory Martin. Przełożył Nowy Testament $\mathrm{z}$ łaciny na język angielski, a adnotacje i komentarze dodał Richard Bristow ${ }^{11}$. Tłumaczenie ukazało się drukiem w 1582 r. w Rheims, we Francji. Znaczącą rolę w pracy translatorskiej Wujka odegrały ponadto polskie niekatolickie przekłady biblijne. Pierwszym z nich była kalwińska Biblia brzeska ${ }^{12}$, zwana też Biblia pińczowska lub Radziwittowską. Wydano ją w Brześciu nad Bugiem w 1563 r., nakładem Mikołaja Radziwiłła Czarnego ${ }^{13}$. Za podstawę jej przekładu posłużyły języki oryginalne - hebrajski i greka oraz łacina. Jednak kilka lat później Szymon Budny skrytykował Biblię brzeska, ponieważ według niego nie opierała się na tekstach hebrajskim i greckim, lecz za mocno czerpała z łacińskich i francuskich przekładów. W 1572 r. w Nieświeżu sam opublikował więc nowe tłumaczenie Biblii, nazwane Bibliq nieświeska. Ponieważ jednak w typografii bez zgody Budnego wprowadzono zmiany w tekście, tłumacz w 1574 r. ogłosił poprawioną wersję Nowego Testamentu ${ }^{14}$.

${ }^{11}$ Zob. D. Frick, Anglo-Polonica. The Rheims New Testament of 1582 and the Making of the Polish Catholic Bible, "The Polish Review”, 36, 1991, s. 52-53.

12 Biblia swięta / Thoiest / Księgi Starego y Nowego Zakonu / wtasnie z Zydowskiego / Greckiego / y Laćińskiego / nowo na Polski ięzyk z pilnośćia y wiernie wytożone, Brześć Litewski: [S. Murmelius lub C. Bazylik?], nakł. M. Radziwiłł, 1563, 2º, BO, sygn. XVI.F.4013 [brak s. 84 z NT].

${ }^{13}$ R. Pietkiewicz, Pismo Święte w języku polskim w latach 1518-1638. Sytuacja wyznaniowa $w$ Polsce a rozwój edytorstwa biblijnego, [rozprawa doktorska], Wrocław 2002, s. 231.

${ }^{14}$ Nowy Testament znowu przetożony / a na wielu mieyscach za pewnemi dowodami od przysad przez Simona Budnego ocżyściony / i krotkiemi przypiskami po kraioch objaśniony. Przydane też sa na końcu tegoż dostateczniejsze przypiskil które każdey iak miarz odmiany przyczyny ukazuia, Łosk: [Daniel z Łęczycy], nakł. J. Kiszka, $1574,8^{\circ}$, BO, sygn. XVI.O.191. 
Tłumaczenie to zostało mocno skrytykowane przez arianina Marcina Czechowica, m.in. za zbytnią dosłowność przekładu. Czechowic w opozycji do Budnego wydrukował zatem w 1577 r. w warsztacie Aleksego Rodeckiego własne tłumaczenie Nowego Testamentu ${ }^{15}$. $\mathrm{Za}$ jego podstawę przyjął trzy wydania greckie NT: Roberta Estienne'a z 1549, Joannesa Crispinusa z 1553, Simona de Colinesa z 1534 r. W komentarzach odwoływał się do Ojców Kościoła i pomocniczo korzystał również z Wulgaty ${ }^{16}$.

Studium komentarzy do Dz 2, $14-36$

Aby zaprezentować metodę pracy Wujka nad komentarzem tekstowym do $\mathrm{Dz} 2,14-36$, należy najpierw przedstawić treść samego tekstu biblijnego ${ }^{17}$, a następnie zestawić tekst Wujkowego komentarza do tego fragmentu z komentarzami NTR 1582 i RB oraz fragmentami polskich przekładów innowierczych. Taka metoda umożliwi udzielenie odpowiedzi na pytanie, czy tłumacz rzeczywiście cytował dzieła Ojców Kościoła i w jakim stopniu był samodzielny w swojej pracy? Dz 2, 14-36 to jeden z tekstów Piotrowych Nowego Testamentu ${ }^{18}$, który w barwny sposób pokazuje, że Wujek wcale nie korzystał z dzieł Ojców Kościoła, ale swój komentarz tekstowy zbudował na podstawie NTR 1582 i RB. Kwestia prymatu Piotrowego, bardzo atakowanego i podważanego przez innowierców w okresie reformacji, pomoże również dostarczyć wielu argumentów odnoszących się do różnych źródeł. W celu precyzyjnego ukazania metody pracy Wujka wszystkie teksty komentarza ciągłego zostaną zestawione w dwóch tabelach.

${ }^{15}$ NOWY TESTAMENT. To iest Wszytkie pisma nowego Przymierza / z Greckiego ięzyka na rzecż Potska wiernie y szcżerze przetożone. Przydane iest rozne cżytanie na brzegach / ktore się $w$ inszych kśięgach nayduie: y Reiestr na końcu, [Kraków]: A. Rodecki, 1577, 4, BO, sygn. XVI.Qu.1773; zob. też R. Pietkiewicz, op. cit., s. 258-259.

${ }^{16}$ R. Pietkiewicz, op. cit., s. 273.

17 Tekst zapisany w transliteracji typu B. Noty marginalne zostały również uwzględnione, jednak nie będą tutaj omawiane, ponieważ temu zagadnieniu poświęciłam wcześniejszy artykuł. Szerzej o marginaliach por. D. Frick, Polish Sacred Philology in the Reformation and the Counter-Reformation (Chapters in the History of the Controversies 1551-1632), Berkeley-Los Angeles-London 1989, s. 155-159.

${ }^{18}$ Artykuł jest tylko wstępną próbą opracowania zagadnienia. Szersze badania nad źródłami dla NTW 1593 zaprezentuję w pracy doktorskiej pt. Nowy Testament w ttumaczeniu ks. Jakuba Wujka z 1593 roku. Studium wykorzystania źródet na przyktadzie tekstów Piotrowych, która powstaje na Papieskim Wydziale Teologicznym we Wrocławiu pod kierunkiem ks. prof. dr. hab. Rajmunda Pietkiewicza. 
Pierwsza zawiera cały komentarz jezuity dotyczący Dz 2, 14-36 wraz z fragmentami z NTR 1582, RB i innymi źródłami, druga natomiast - szczegółową metodologię Wujkowej pracy ze źródłami ${ }^{19}$. Z całości komentarza Wujkowego wyodrębniono bowiem następujące kategorie tekstów: 1) dosłownie przetłumaczone $\mathrm{z}$ angielskiego lub łaciny, 2) stanowiące parafrazę NTR 1582 albo RB, 3) własne odnośniki tłumacza do paralelnych miejsc biblijnych, 4) fragmenty zaczerpnięte z polskich innowierczych przekładów biblijnych, 5) odnośniki do terminów greckich i łacińskich, 6) passusy niepochodzące ani z NTR 1582, ani z RB, być może zaczerpnięte $\mathrm{z}$ jakiegoś innego, jeszcze niezidentyfikowanego źródła. Każdemu dopasowanemu do danej kategorii tekstowi ściśle odpowiada fragment z NTR 1592, RB albo inny. Fragmenty komentarza Wujka ujęte w pierwszej tabeli, a nieujęte w drugiej, to jego własne dodatki.

Tekst Dz 2, $14-36$ z N TW $1593^{20}$

14. A stanąwszy Piotr z jedennaścią, podniósł głos swój i odpowiedział im: Mężowie Żydowscy i wszyścy, którzy mieszkacie w Jeruzalem, niech to wam jawno będzie, a przyjmicie do uszu słowa moje.

15. Abowiem nie sąć pijani ci, jako wy mniemacie, gdyż jest trzecia godzina na dzień,

16. aleć to jest co powiedziano przez Proroka Joela:

17. ${ }^{d}$ I będzie, w ostateczne dni (mówi "Pan) wyleję z Ducha mego na wszelkie ciało, a prorokować będą synowie waszy i córki wasze, a młodzieńcy waszy widzenia będą miewać, a starcom waszym "sny się śnić będą.

18. A k temu w oneż dni, na sługi me, i na służebnice moje wyleję z Ducha mego, i będą prorokować,

${ }^{19} \mathrm{~W}$ pracy doktorskiej stosuję oznaczenia kolorami, dla przejrzystego ukazania różnic i podobieństw między tekstem komentarza Wujka a innymi źródłami. Tutaj jednak, ze względu na brak możliwości ukazania szczególów w kolorze, w dodatkowej tabeli zestawiam poszczególne fragmenty komentarza Wujka z dokładnie dopasowanymi do nich innymi tekstami źródłowymi tak, aby ułatwić czytelnikowi lekturę.

${ }^{20}$ Objaśnienia symboli graficznych stosowanych przez Wujka są następujące: * oznacza, że w oryginale znajdowało się jakieś słowo, które Wujek pominął, np. * i 5 L. G. S. oznacza, że 5 ksiąg tacińskich, greckich i syryjskich wymienia „i”, a Wujek je pomija. W tekście NTR 1582 * oznacza odnośnik do innego dzieła. Litera $\mathrm{w}$ indeksie górnym (np. ${ }^{d}$ ) wraz z przypisanymi do niej siglami biblijnymi oznacza paralelne miejsce w tekście biblijnym. Symbole "'oraz" oznaczają wykład miejsc trudniejszych lub różnice w poszczególnych księgach, np. "śmierci G. oznacza, że księgi greckie mają w tym miejscu wyraz „śmierci”, natomiast Wujek zamiast niego podaje „piekła”. Słowo zapisane w indeksie górnym oznacza własny dodatek Wujka. 
19. i dam cuda na niebie wzgórę i znamiona na ziemi nisko, krew, i ogień, i kurzawę dymu.

20. Słońce się obróci w ciemność, a księżyć w krew, przedtym niż przyjdzie on dzień Pański wielki i znaczny.

21. I stanie się, ${ }^{e}$ iż wszelki którybykolwiek wzywał imienia Pańskiego, zbawion będzie.

22. Mężowie Izraelscy, słuchajcie słów tych. Jezusa Nazareńskiego, męża od Boga pochwalonego u was mocami i cudami i znamiony, które czynił Bóg przezeń między wami, jako * sami wiecie,

23. tego naznaczoną radą i przejźrzenim Bożym wydanego, * przez ręce niezbożników przybiwszy do krzyża zatraciliście.

24. Którego Bóg wzbudził rozwiązawszy boleści " piekła, jakoż była rzecz niepodobna, aby od niego miał być on zatrzyman.

25. Abowiem Dawid o nim mówi: ${ }^{f}$ Upatrowałem zawżdy Pana przed sobą, bo mi jest po prawicy, abych nie był wzruszon.

26. Dla tegoż się rozweseliło serce moje, a rozdarował się język mój, nad to i ciało moje odpocznie w nadziei.

27. Abowiem nie zostawisz dusze mojej w piekle, ani dasz świętemu twemu oglądać "skażenia'.

28. "Oznajmiłeś drogi żywota', napełnisz mię radością "z obliczem twoim.

29. Mężowie bracia, niech mogę bezpiecznie mówić ku wam o Patriarsze Dawidzie, ${ }^{g}$ że * umarł i pogrzebion jest, i grób jego jest u nas, aż do dnia dzisiejszego.

30. Będąc tedy Prorokiem, i wiedząc że ${ }^{b}$ mu Bóg obiecał pod przysięgą, iż z owocu biodr jego * miał posadzić na stolicy jego,

31. przeglądając powiedział o zmartwychwstaniu Chrystusowym, iż ${ }^{i "}$ ani zostawion jest w piekle', ani ${ }^{k}$ ciało jego ujźrzało zepsowania'.

32. Tegoć Jezusa wzbudził Bóg, l' czego my wszyścy jesteśmy świadkowie.

33. Prawicą tedy Bożą bẹdąc podwyższony, a obietnicę Ducha Świętego wziąwszy od Ojca, wylał" tego, którego' wy * widzicie i słyszycie.

34. Abowiem Dawid nie wstąpił do nieba, lecz sam powieda: ${ }^{m}$ Rzekł Pan Panu memu: siądź na prawicy mojej,

35. aż położę nieprzyjacioły twe podnóżkiem nóg twoich.

36. Niechajżeć tedy wie za pewne wszytek dom Izraelski, iż go i Panem, i "Chrystusem’ uczynił Bóg, tego to Jezusa, któregoście wy ukrzyżowali.

\section{Komentarz marginalny}

14. Piotr jako głowa wszystkich Apostołów, po zesłaniu Ducha Ś. pierwsze czyni kazanie.

17. "Bóg. G.

"To jest przez sny pokaże im wolą moję.

20. G.

22. * i. 5 L. G. S.

23. * poimawszy. G.

24. "śmierci. G. 
27. "skazić się. Hebr.

28. "przywróciłeś mi żywot. Hebr. "z obliczności twojej. Hebr.

29. * i. 4 L. G. S.

30. * ile wedle ciała Chrystusa miał wzbudzić. G.

31. "nie miała zostać dusza jego. G. "nie skaziło się. Hebr.

33. "ten dar który. NL. S. to co. G. * teraz G.

36. "królem. Hebr.

\section{Odsytacze do miejsc paralelnych}

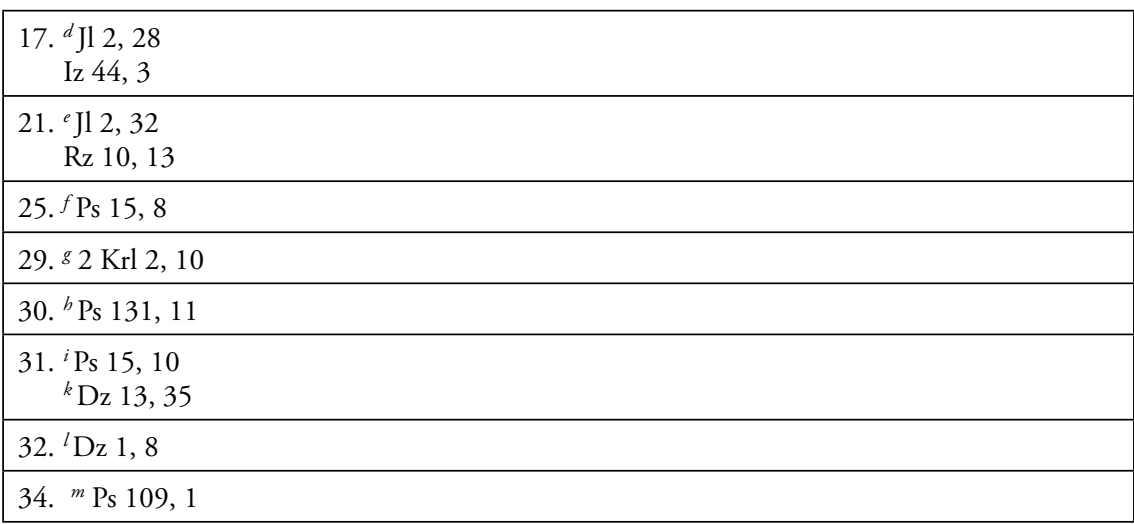


Tabela 1. Komentarz tekstowy

\begin{tabular}{|c|c|}
\hline Wujkowy komentarz Nauki i przestrogi & Angielski komentarz z Rheims i łaciński komentarz Roberta Bellarmina \\
\hline [zewn.: PIOTR WSZĘDY PRZODKUJE] & $\begin{array}{l}\text { [zewn.: GOS DETERMINATION THAT CHRIST SHOULD DIE, } \\
\text { EXCUSETH NOT THE IEWES] }\end{array}$ \\
\hline 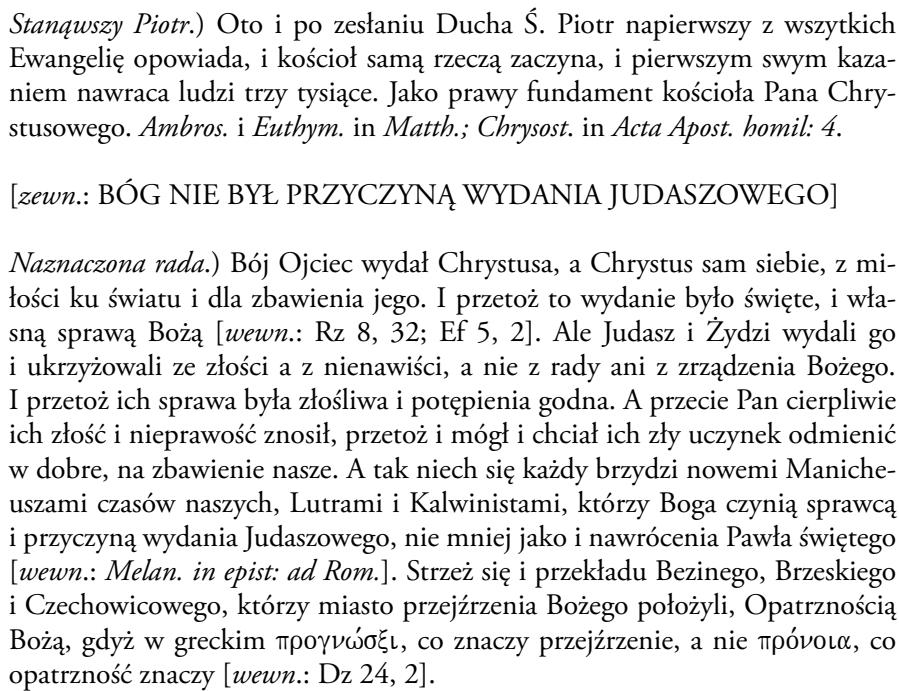 & 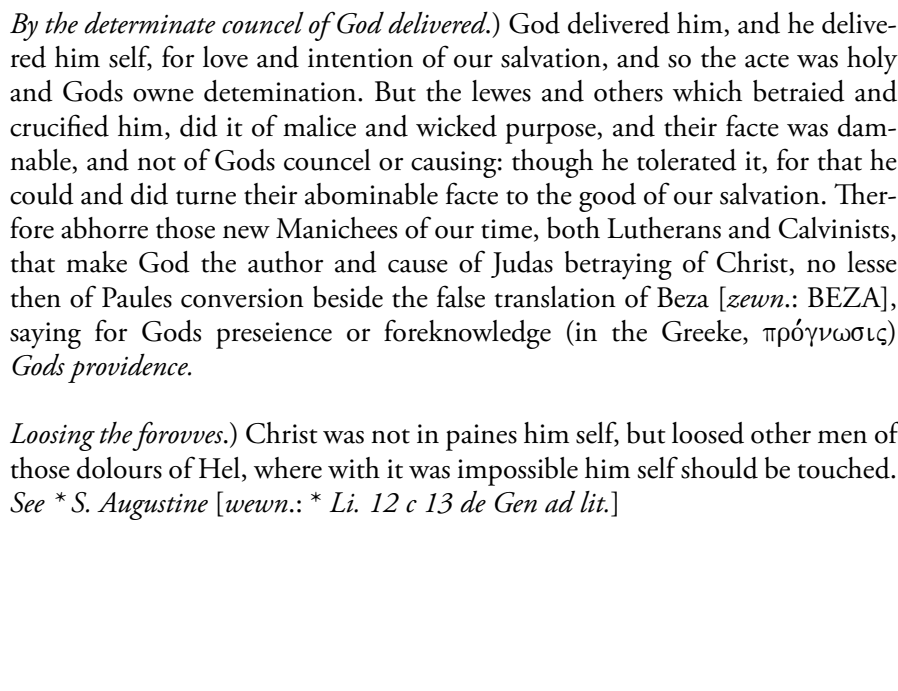 \\
\hline$[$ zewn.: CZYŚCIEC $]$ & \\
\hline $\begin{array}{l}\text { Rozwiazawszy boleści piekielne.) To miejsce tak rozumie Augustyn święty, } \\
\text { że Chrystus zstapiwiwszy do piekła wybawił mnogich od boleści piekielnych } \\
\text { [wewn.: epist. 99; } 10 \text { lib. 12; Jene. 33; Heres. Tatiani]. Co iż się o potępionych }\end{array}$ & \\
\hline
\end{tabular}


rozumieć nie może, musi się rozumieć o tych którzy byli w czyśćcu. Bo i Epiphanius pisze, iż Pan Chrystus gdy zstąpił do piekła, wybawił te którzy acz z niewiadomości grzeszyli, wszakże od wiary Bożej nie odstąpili. Ale mimo te świadectwa, dowieść tego możemy i z samego tekstu. Abowiem te słowa, rozwiązawszy boleści piekielne, nie mogą się rozumieć o boleściach samego Chrystusa, bo jego boleści na krzyżu koniec wzięły. Co się i z onych słów okazuje: dzisiaj będziesz ze mną w raju [wewn.: Łk 23, 43]. Ani się mogą rozumieć o boleściach ludzi potępionych, bo te boleści w ogniu onym wiecznym nigdy się nie skończą. Ani o boleściach ojców świętych, bo ci żadnych boleści nie cierpieli, jako Augustyn Ś. uczy na miejscach naznaczonych, i Grzegorz święty [wewn.: Greg. hom: 22]. A tak koniecznie rozumieć się muszą o boleściach onych którzy byli w czyśccu. A choć w niektórych greckich księgach stoi, Boleści śmierci, a nie Boleści piekła, wszakże Łacińskie stare, i Greckie niektóre, i Syryjskie zgodnie mają piekła; i najstarsi ojcowie Greccy i Łacińscy tak czytali. Święty Polikarpus, Ś. Cyprian, Ś. Epiphanius i Augustyn święty. Co się z słów poślednich Piotra świętego dosyć okazuje, kędy tego co rzekł, dowodzi temi słowy z Psalmu: Nie zostawisz dusze mojej w piekle [wewn.: Ps 15, 10].

\section{[zewn.: HERETYCY FAESZUJĄ TEKST PISMA Ś.]}

Dusze mojej w piekle.) To miejsce heretykowie szkaradzie sfałszowali. Beza tak pierwej przełożył: Nie zostawisz trupa mego w grobie. Potym tak poprawił: Nie zostawisz ciała mego w grobie, jako i Brześcy tłumacze z niego przełożyli. Acz trochę niżej tego trupa przecie nie zaniechali, tak przekładając: Iż nie został w grobie trup jego [zewn.: Ewangelikowie duszę w trupa, a piekto w grób przemieniaja.]. Wstydliwszy trochę byli Nowokrzczeńcy Budny i Czechowic, którzy duszę w trupa abo w ciało przemienić, nie śmiejąc, przełożyli: Nie zo-

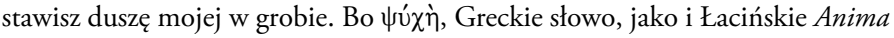
i Polskie Dusza, nigdy nie znaczy trupa ani ciała, ale właśnie duszę. A przetoż faleszna jest ta Budnego gloza: Dusze, to jest ciała. A tak Kalwinistowie duszę w trupa abo w ciało przemienili, a Nowokrzczeńcy z nimi piekło w grób przetworzyli, i duszę Pańską w grobie zagrzebli, chociaż po Grecku nie jest

\section{[zewn.: CORRUPT TRANSLATION AGAINST THE ARTICLE OF CHRIST DESCENDING INTO HEL]}

My soul in Hel.) Where al the Faithful, according to the Creede, ever have belecued, that Christ according to his soul, went downe to Hel, to deliver the Patriarches and al iust men there holden in bondage til his death, and the Apostle here citing the Prophets Wordes, most evidently expresseth the same, distinguishing his soule in Hel, his [.....] the grave: Yet the Calvinists to defend against Gods expresse wordes, the blashpemie of their Maister, that Christ suffered th paines of Hel, and that no where but upon the Crosse, and that otherwise he descended not info Hel, most falsely and flatly here corrupt the texts, by turning and wresting both the Hebrew and Greeke wordes [zewn.:

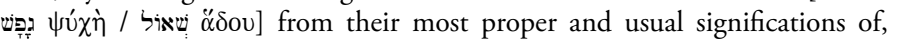
Soule, and Hel into Body, and grave: saying for, my soule in Hel, thus my body, * life, person, yea [wewn.: * Eng. Bible 1579] (as Beza in his New Testament 


\begin{tabular}{|c|c|}
\hline Wujkowy komentarz Nauki i przestrogi & Angielski komentarz z Rheims i łaciński komentarz Roberta Bellarmina \\
\hline 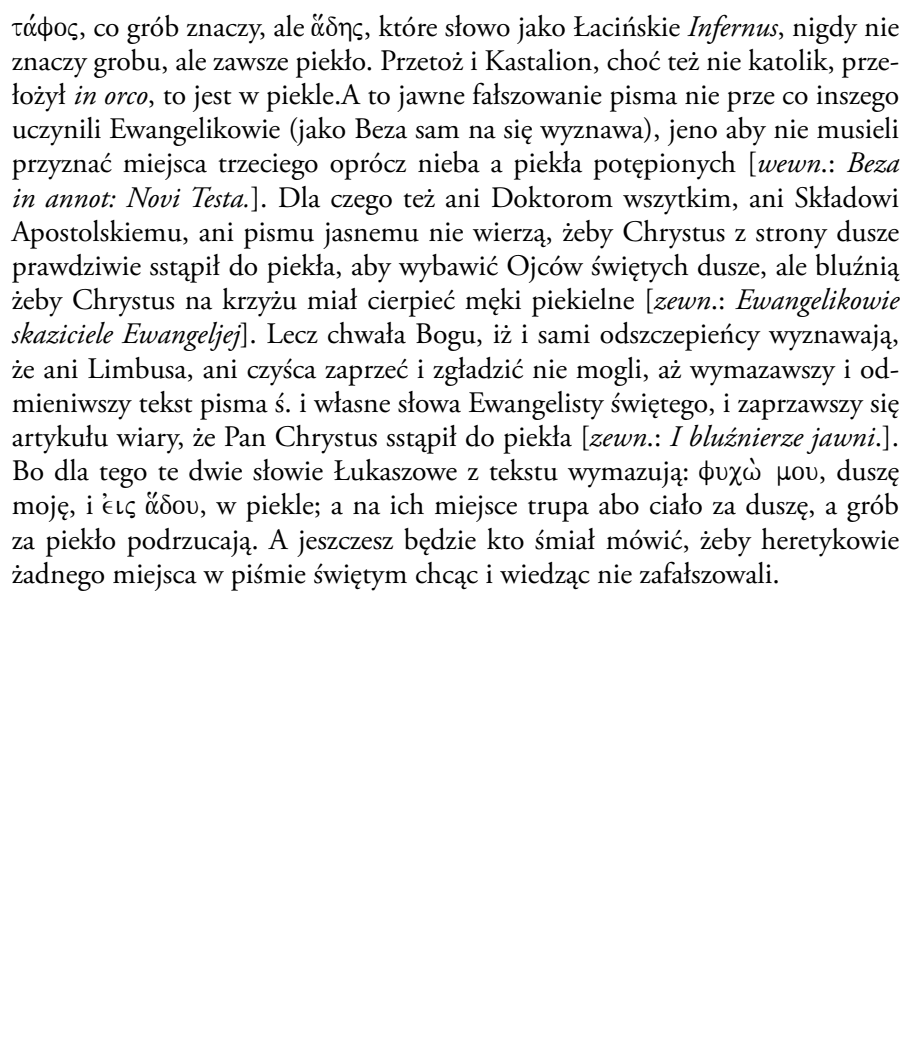 & 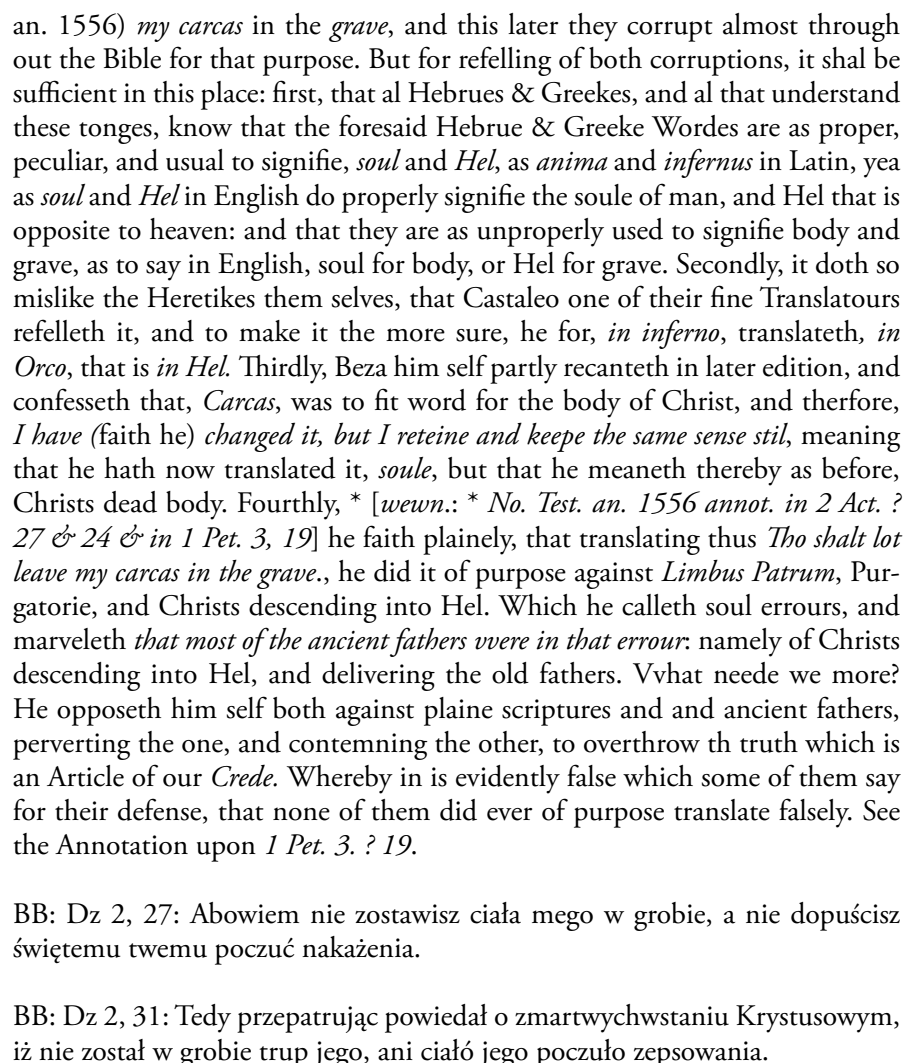 \\
\hline
\end{tabular}




\section{[zewn.: BÓSTWO CHRYSTUSOWE]}

Ile wedle ciata.) Tak w Greckim czytają. Stąd się okazuje, iż w Chrystusie było coś zacniejszego niźli samo ciało, to jest bóstwo jego.

\section{[zewn.: CHRYSTUS JAKO PANEM JEST UCZYNIONY]}

Panem i Chrystusem uczynit Bóg.) Chrystus uczynion jest Panem od Ojca (jako Cyrillus dobrze wykłada) [wewn.: Lib. 9. Thesau.] z strony człowieczeństwa, którym sposobem możemy rzec, że jest uczynion i Bogiem. Abowiem się to przez wcielenie stało, że on człowiek Jezus jest Bogiem i Panem, nie przez uczestnictwo i łaskę, ale przez unię Słowa z ciałem. Acz się i tak rozumieć może (jako tenże Cyrillus przypomina) uczynił go Panem i Bogiem, to jest oznajmił go i pokazał być Panem i Bogiem. Jako Paweł mówi: Dał mu imię które jest nad wszelkie imię [wewn.: Fil 2, 9].
NTSzB: Dz 2, 31: Przepatrując powiedział o wstaniu Krystusowym, iż nie została w piekle dusza jego, ani ciało jego widziało zepsowania.

NTMCz: Dz 2, 27: Abowiem nie zostawisz dusze mojej w grobie, ani dasz świętemu twemu oglądać skażenia.

Hu caccedit consensus fere omnium illorum, qui de hac re iudicare poterant.

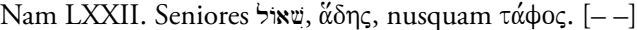

Quartus locus est Actor. 2. Non relinques animam meam in inferno. Beza vertit, Non cadaver meum in sepulcro. Et in defensione huius versionis contra Sebastianum Castalionem, Hic, inquit, agi de corpore \& sepulcro nemo dubitare potest, nisi quis velit meridie caecuire.

Decimatertiaest Actor. 3 ubi post acceptum Spiritum sanctum Petrus omnium primus promulgat Evangelium, \& prima illa concione tria milia hominum convertit.

236 C: Deus Pater, Deus Filius, Deus Spiritus Sanctus, \& tamen non tresDij, sed unus est Deus. Ciril. lib. 9.

254 E: Cyrillus lib. 9. c. 37. in Ioannem, convincit ex hoc loco, Christum esse unum Deum cum Patre.

306 A: Ad locum Act. 2. Respondeo cum Cyrillo lib. 9 Thesauri., c. 3. Christum factum dominum a Patre ratione humanitatis, quomodo etiam posset dicifactus Deus, id enim factum est per incarnationem, utille homo Iesus sit Deus, \& dominus, non per participationem, \& gratiam, sed per unionem Verbi\& carnis. 
Tabela 2. Wujkowa metodologia pracy ze źródłami - zestawienie fragmentów

\begin{tabular}{|c|c|}
\hline Wujkowy komentarz Nauki i przestrogi & $\begin{array}{c}\text { Angielski komentarz z Rheims, łaciński komentarz Roberta Bellarmina } \\
\text { i inne źródła }\end{array}$ \\
\hline \multicolumn{2}{|l|}{ Dosłowne thumaczenia } \\
\hline $\begin{array}{l}\text { Oto i po zesłaniu Ducha Ś. Piotr napierwszy z wszytkich Ewangelię opowiada, } \\
\text { i kościoł samą rzeczą zaczyna, i pierwszym swym kazaniem nawraca ludzi trzy } \\
\text { tysiące. }\end{array}$ & $\begin{array}{l}\text { Post acceptum Spiritum sanctum Petrus omnium primus promulgat Evange- } \\
\text { lium, \& prima illa concione tria milia hominum convertit. }\end{array}$ \\
\hline Dusze mojej w piekle.) & My soul in Hel.) \\
\hline Przetoż i Kastalion, choć też nie katolik, przełożył in orco, to jest w piekle. & $\begin{array}{l}{[--] \text { that Castaleo one of their fine Translatours refelleth it, and to make it the }} \\
\text { more sure, he for, in inferno, translateth, in Orco, that is in Hel. }\end{array}$ \\
\hline $\begin{array}{l}\text { Abowiem się to przez wcielenie stało, że on człowiek Jezus jest Bogiem i Pa- } \\
\text { nem, nie przez uczestnictwo i łaskę, ale przez unię Słowa z ciałem. }\end{array}$ & $\begin{array}{l}\text { Quomodo etiam posset dici factus Deus, id enim factum est per incarnatio- } \\
\text { nem, ut ille homo Iesus sit Deus, \& dominus, non per participationem, \& } \\
\text { gratiam, sed per unionem Verbi \& carnis. }\end{array}$ \\
\hline \multicolumn{2}{|l|}{ Teksty zaczerpnięte z innego, jeszcze niezidentyfikowanego źródła } \\
\hline $\begin{array}{l}\text { Jako prawy fundament kościoła Pana Chrystusowego. Ambros. i Euthym. in } \\
\text { Matth.; Chrysost. in Acta Apost. homil: } 4 .\end{array}$ & brak \\
\hline $\begin{array}{l}\text { A tak niech się każdy brzydzi nowemi Manicheuszami czasów naszych, Lu- } \\
\text { trami i Kalwinistami, którzy Boga czynią sprawcą i przyczyną wydania Juda- } \\
\text { szowego, nie mniej jako i nawrócenia Pawła świętego [wewn.: Melan. in epist: } \\
\text { ad Rom.]. }\end{array}$ & brak \\
\hline $\begin{array}{l}\text { To miejsce tak rozumie Augustyn święty, że Chrystus zstąpiwszy do piekła } \\
\text { wybawił mnogich od boleści piekielnych [wewn.: epist. 99; } 10 \text { lib. 12; Jene. } \\
\text { 33; Heres. Tatiani]. Co iż się o potępionych rozumieć nie może, musi się rozu- } \\
\text { mieć o tych którzy byli w czyśćcu. Bo i Epiphanius pisze, iż Pan Chrystus gdy }\end{array}$ & brak \\
\hline
\end{tabular}


zstąpił do piekła, wybawił te którzy acz z niewiadomości grzeszyli, wszakże od wiary Bożej nie odstąpili.

Ani się mogą rozumieć o boleściach ludzi potępionych, bo te boleści w ogniu onym wiecznym nigdy się nie skończą. Ani o boleściach ojców świętych, bo ci żadnych boleści nie cierpieli, jako Augustyn Ś. uczy na miejscach naznaczonych, i Grzegorz święty [wewn.: Greg. hom: 22]. A tak koniecznie rozumieć się muszą o boleściach onych którzy byli w czyśccu.

I najstarsi ojcowie Greccy i Łacińscy tak czytali. Święty Polikarpus, Ś. Cyprian, Ś. Epiphanius i Augustyn święty.

\section{Odnośniki tłumacza do paralelnych fragmentów biblijnych}

Bój Ojciec wydał Chrystusa, a Chrystus sam siebie, z miłości ku światu i dla zbawienia jego. I przetoż to wydanie było święte, i własną sprawą Bożą [wewn.: Rz 8, 32; Ef 5, 2].

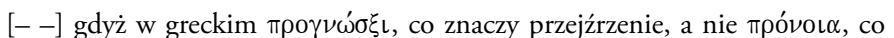
opatrzność znaczy [wewn.: Dz 24, 2].

Co się i z onych słów okazuje: dzisiaj będziesz ze mną w raju [wewn.: Łk 23, 43].

Nie zostawisz dusze mojej w piekle [wewn.: Ps 15, 10].

Jako Paweł mówi: Dał mu imię które jest nad wszelkie imię [wewn.: Fil 2, 9].

\section{Parafrazy}

To miejsce heretykowie szkaradzie sfałszowali. Beza tak pierwej przełożył: Nie zostawisz trupa mego w grobie. Potym tak poprawił: Nie zostawisz ciała mego $\mathrm{w}$ grobie.

Where al the Faithful, according to the Creede, ever have belecued, that Christ according to his soul, went downe to Hel, to deliver the Patriarches and al iust men there holden in bondage til his death, and the Apostle here 


\begin{tabular}{|c|c|}
\hline Wujkowy komentarz Nauki i przestrogi & $\begin{array}{l}\text { Angielski komentarz z Rheims, laciński komentarz Roberta Bellarmina } \\
\text { i inne źródła }\end{array}$ \\
\hline 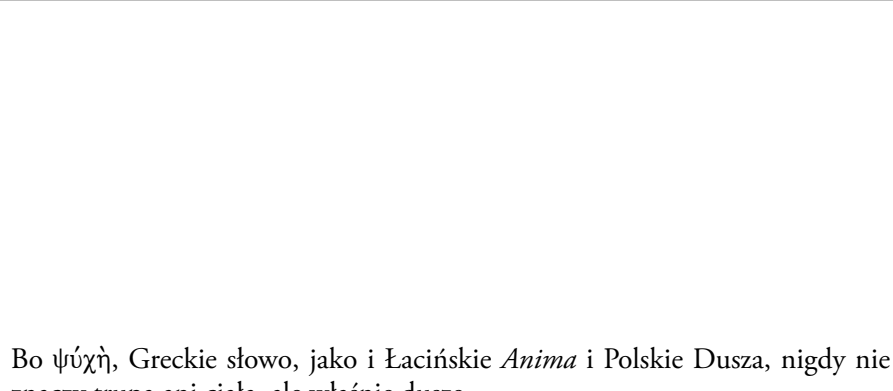 & 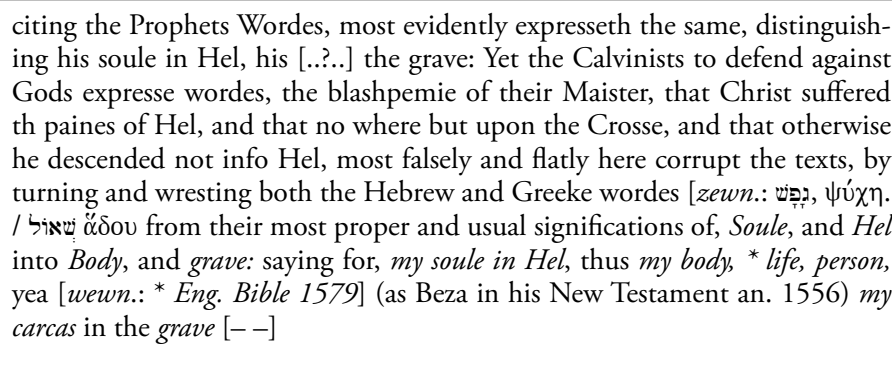 \\
\hline 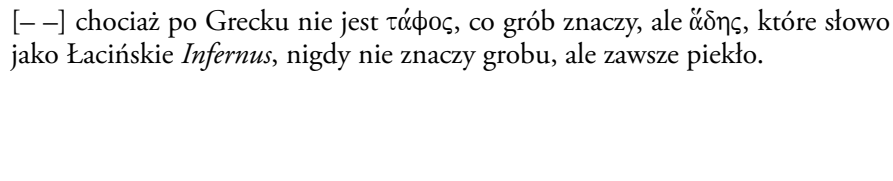 & $\begin{array}{l}\text { Hebrue \& Greeke Wordes are as proper, peculiar, and usual to signifie, soul } \\
\text { and Hel, as anima and infernus in Latin, yea as soul and Hel in English do } \\
\text { properly signifie the soule of man and Hel that is opposite to heaven: and that } \\
\text { they are as unproperly used to signifie body and grave, as to say in English, } \\
\text { soul for body, or Hel for grave. }\end{array}$ \\
\hline $\begin{array}{l}\text { A to jawne fałszowanie pisma nie prze co inszego uczynili Ewangelikowie } \\
\text { (jako Beza sam na się wyznawa) jeno aby nie musieli przyznać miejsca trzecie- } \\
\text { go oprócz nieba a piekła potępionych [wewn.: Beza in annot: Novi Testa.]. Dla } \\
\text { czego też ani Doktorom wszytkim, ani Składowi Apostolskiemu, ani pismu } \\
\text { jasnemu nie wierza, żeby Chrystus z strony dusze prawdziwie sstapił do pie- } \\
\text { kła, aby wybawić Ojców świętych dusze, ale bluźnią żeby Chrystus na krzyżu } \\
\text { miał cierpieć męki piekielne. }\end{array}$ & $\begin{array}{l}\text { Thirdly, Beza him self partly recanteth in later edition, and confesseth that, } \\
\text { Carcas, was to fit word for the body of Christ, and therfore, I have (faith he) } \\
\text { changed it, but I reteine and keepe the same sense stil, meaning that he hath now } \\
\text { translated it, soule, but that he meaneth thereby as before, Christs dead body. } \\
\text { Fourthly, * [wewn.: }{ }^{*} \text { No. Test. an. } 1556 \text { annot. in } 2 \text { Act. ? } 27 \& 24 \& \text { in } 1 \text { Pet. } \\
3,19] \text { he faith plainely, that translating thus Tho shalt lot leave my carcas in the } \\
\text { grave., he did it of purpose against Limbus Patrum, Purgatorie, and Christs de- } \\
\text { scending into Hel. Which he calleth soul errours, and marveleth that most of } \\
\text { the ancient fathers vvere in that errour: namely of Christs descending into Hel, } \\
\text { and delivering the old fathers. Vvhat neede we more? He opposeth him self } \\
\text { both against plaine scriptures and and ancient fathers, perverting the one, and } \\
\text { contemning the other, to overthrow tht truth which is an Article of our Crede. }\end{array}$ \\
\hline
\end{tabular}


Lecz chwała Bogu, iż i sami odszczepieńcy wyznawają, że ani Limbusa, ani czyśca zaprzeć i zgładzić nie mogli, aż wymazawszy i odmieniwszy tekst pisma ś. i własne słowa Ewangelisry świętego, i zaprzawszy się artykułu wiary, że Pan Chrystus sstąpił do piekła.

Chrystus uczynion jest Panem od Ojca (jako Cyrillus dobrze wykłada) [wewn.: Lib. 9. Thesau.] z strony człowieczeństwa, którym sposobem możemy rzec, że jest uczynion i Bogiem.

Acz się i tak rozumieć może (jako tenże Cyrillus przypomina) uczynił go Panem i Bogiem, to jest oznajmił go i pokazał być Panem i Bogiem.

\section{Odnośniki do polskich innowierczych przekładów biblijnych}

Strzeż się i przekładu Bezinego, Brzeskiego i Czechowicowego, którzy miasto przejźrzenia Bożego położyli, Opatrznością Bożą [- - ]

Nie zostawisz ciała mego w grobie, jako i Brześcy tłumacze z niego przełożyli. Acz trochę niżej tego trupa przecie nie zaniechali, tak przekładając: Iż nie został w grobie trup jego.
Huc accedit consensus fere omnium illorum, qui de hac re iudicare poterant.

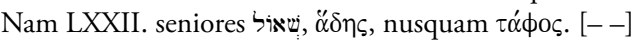

Quartus locus est Actor. 2. Non relinques animam meam in inferno. Beza vertit, Non cadaver meum in sepulcro. Et in defensione huius versionis contra Sebastianum Castalionem, Hic, inquit, agi de corpore \& sepulcro nemo dubitare potest, nisi quis velit meridie caecuire.

Deus Pater, Deus Filius, Deus Spiritus Sanctus, \& tamen non tres Dij, sed unus est Deus. Ciril. lib. 9.

Cyrillus lib. 9. c. 37. in Ioannem, convincit ex hoc loco, Christum esse unum Deum cum Patre.

Ad locum Act. 2. Respondeo cum Cyrillo lib. 9 Thesauri., c. 3. Christum factum dominum a Patre ratione humanitatis,

BB: Dz 2, 27: Abowiem nie zostawisz ciała mego w grobie, a nie dopuścisz świętemu twemu poczuć nakażenia.

BB: Dz 2, 31: Tedy przepatrując powiedał o zmartwychwstaniu Krystusowym, iż nie został w grobie trup jego, ani ciało jego poczuło zepsowania. 


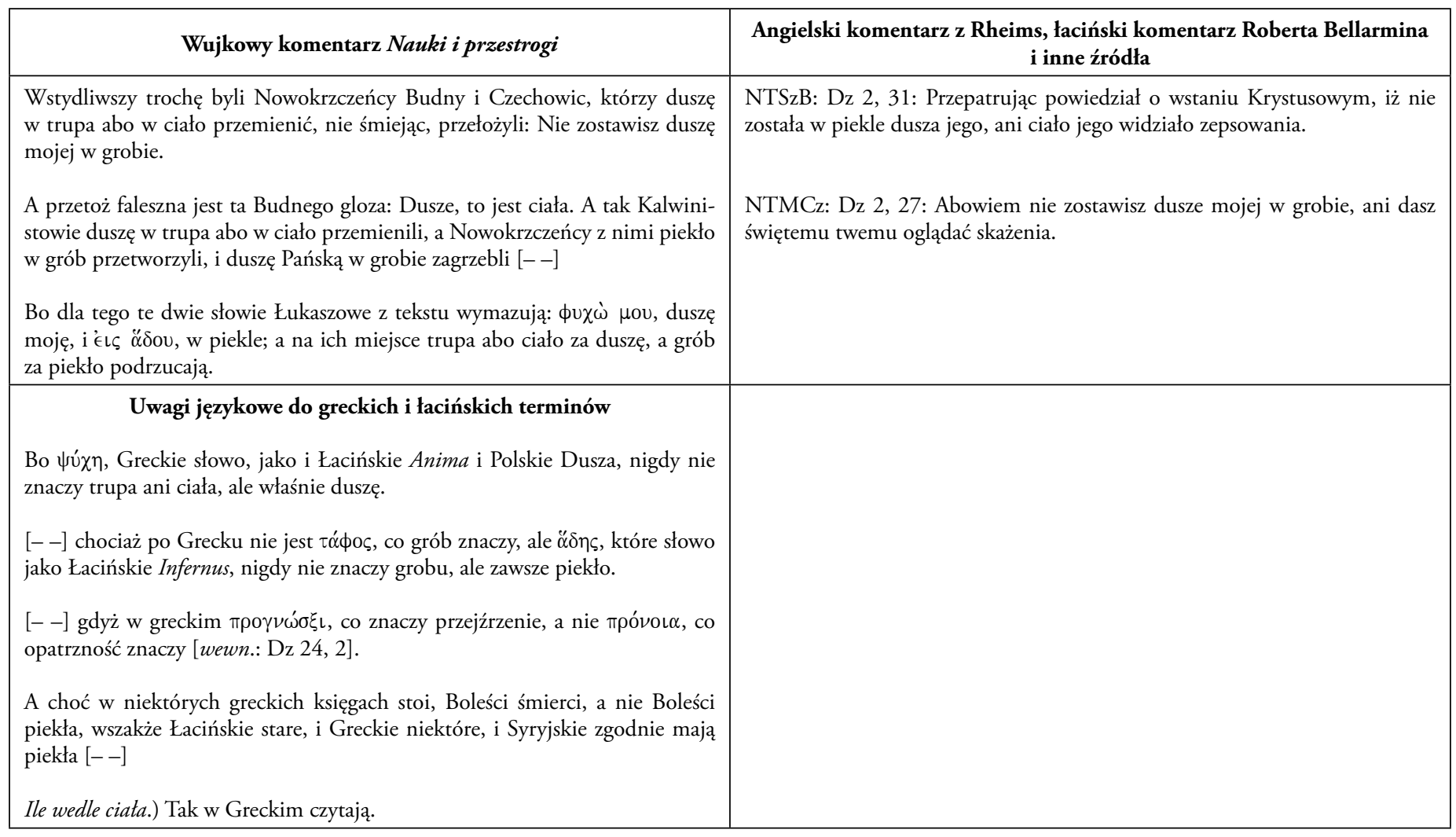


W tym obszernym fragmencie uwidacznia się Wujkowa erudycja i niezwykła zdolność dokonywania syntezy. Mniej tekstów jest dosłownie przetłumaczonych, za to sporo sparafrazowanych, kilka zaczerpniętych z innego (jeszcze niezidentyfikowanego) źródła. Pojawiają się także odnośniki do podobnych tekstów biblijnych, ale na szczególną uwagę zasługuje widoczna polemika $\mathrm{z}$ innowiercami. Wujek doskonale orientował się w niekatolickich polskich przekładach biblijnych, takich jak Biblia brzeska, Nowy Testament w tłumaczeniu Szymona Budnego czy Nowy Testament Marcina Czechowica i umiejętnie wykazał w nich błędy. Nie brakuje również terminologii greckiej czy łacińskiej, co także świadczy o ogromnym obeznaniu Wujka z różnymi tłumaczeniami biblijnymi.

Studium Dz 2, 14-36 pokazuje, że Wujek jako komentator nie był samodzielny $\mathrm{w}$ pisaniu komentarza tekstowego. Podobnie jak w przypadku not marginalnych, również i tutaj posiłkował się źródłami. Jego komentarz tekstowy, polemicznie ustosunkowujący się do poglądów innowierców i ich translacji, stanowił apologię wiary katolickiej i kompilację tekstów kilku komentarzy. To oznacza, że Wujek nie korzystał ze wszystkich dzieł Ojców Kościoła i nie cytował ich, ale opierał się na innych książkach, które stanowiły kompendium potrzebnych tekstów patrystycznych. Można jednak to zrozumieć, zwłaszcza że w XVI w. nie istniało pojęcie prawa autorskiego ani plagiatu. Wujek nieustannie podróżował, nie mógł zatem przewozić na wozie zaprzęgniętym w konie całej biblioteki! Wydaje się logiczne i uzasadnione, iż musiał mieć podręczny, prywatny księgozbiór złożony z kilkunastu książek, których akurat potrzebował i był w stanie zabierać ze sobą w każdą podróż. Historia Akademii Wileńskiej, gdzie Wujek przez krótki czas pełnił funkcję rektora, pokazuje, że komentarz Roberta Bellarmina należał do utworów powszechnie znanych i czytanych w środowisku jezuickim. Jeśli zaś chodzi o znajomość języka angielskiego, to istnieje duże prawdopodobieństwo, że Wujek sam się go nauczył, aby w swojej pracy opierać się na tekstach z NTR 1582. Przebywając w międzynarodowym środowisku jezuickim i posiadając talent do nauki języków obcych, mógł opanować angielski, żeby pracować samodzielnie i nie korzystać z pomocy jakiegoś współbrata Anglika. Wprawdzie u jezuitów nie brakowało wówczas zakonników angielskiego pochodzenia ${ }^{21}$, jednak brak źródeł,

${ }^{21}$ Dariusz Kuźmina (idem, Pod sztandarem stowa, Warszawa 2004, s. 38) wymienia chociażby Wilhelma Lamberta, Ludwik Piechnik (idem, Poczatki Akademii 
które jednoznacznie wskazywałyby u Wujka na fakt posługiwania się wsparciem anglojęzycznego tłumacza ${ }^{22}$. Przeprowadzone studium nieco umniejsza autorytet Jakuba Wujka, jednak nie podważa go całkowicie. Należy pamiętać, że jak na XVI w. biblista z Wągrowca zdobył znakomite wykształcenie. Władał kilkoma językami obcymi i nawet jeśli nie sięgał do dzieł Ojców Kościoła, a korzystał z gotowych opracowań, to i tak włożył mnóstwo pracy w opracowanie komentarza do NTW 1593. Nie przepisywał wszystkiego od początku do końca, ale wykazywał się inwencją twórczą. Niektóre teksty tłumaczył dosłownie i nawet graficznie je odwzorowywał, inne jednak parafrazował (streszczał, skracał, pomijał). Czynił też sporo własnych uwag oraz odwoływał się do paralelnych historii biblijnych. Wreszcie wykonał jedno z najważniejszych i zleconych mu zadań: dostosował swój przekład NTW 1593 wraz z komentarzem do realiów polskich, korzystając $\mathrm{z}$ innowierczych polskich przekładów biblijnych i polemizując $\mathrm{z}$ nimi.

\section{Wykaz skrótów}

BB - Biblia brzeska, zwana też pińczowska lub Radziwittowska

G. - (teksty) greckie

Hebr. - hebraizm

L. G. S. - (teksty) łacińskie, greckie, syryjskie

$\mathrm{NL}$ - niektóre teksty łacińskie

NT - Nowy Testament

NTMCz - tłumaczenie Nowego Testamentu Marcina Czechowica, opublikowane w 1577 r. w warsztacie Aleksego Rodeckiego

NTR 1582 - Nowy Testament z Rheims, opublikowany w 1582 r.

NTSzB - tłumaczenie Nowego Testamentu Szymona Budnego, opublikowane w 1574 r. w Łosku

NTW 1593 - Nowy Testament w tłumaczeniu Jakuba Wujka, opublikowany w $1593 \mathrm{r}$.

Wileńskiej (1570-1599), Rzym 1984, s. 47, 105, 146) natomiast Adama Brocka, Artura Faunta i Jakuba Bosgrave'a.

${ }^{22}$ Wujek nie wspomina o tym w ogóle w swojej korespondencji listownej z przełożonymi. Można przypuszczać, że gdyby korzystał z pomocy angielskiego tłumacza, to zawarłby tę informację w swoich sprawozdaniach; zob. J. Sygański, Korespondencja ks. Jakóba Wujka z Wagrówca z lat 1569-1596, „Roczniki Towarzystwa Przyjaciół Nauk Poznańskiego”, 44, 1918, s. 297-359; 45, 1918, s. 127 -160 ; 46, 1920, s. $1-110$. 
RB - Robert Bellarmin, Disputationes de Controversiis Christianae Fidei adversus huius temporis haereticos, Ingolstadt 1581-1593

wewn. - margines wewnętrzny

zewn. - margines zewnętrzny

\section{Bibliografia}

Biblia swięta / Thoiest / Ksiegi Starego y Nowego Zakonu / wtasnie z Zydowskiego / Greckiego / y Laćińskiego / nowo na Polski ięzyk z pilnościa y wiernie wytożone, Brześć Litewski: [S. Murmelius lub C. Bazylik?], nakł. M. Radziwiłt, 1563, 2 , BO, sygn. XVI.F.4013

BIBLIA TO IEST KSIĘGI STAREGO Y NOWEGO TESTAMNETV WEDEVG EACINSKIEGO przektadu starego, w kościele powszechnym przyiętego, na Polski ięzyk z nowu z pilnośćia przetożone, Z DOKEADANIEM TEXTV ZYDOWSKIEGO y Greckiego, y z wyktadem Katholickim, trudnieyszych mieysc do obrony Wiary swiętey powszechney przeciw kacerztwóm tych czasów nalezacych: PRZEZ D. IAKVBA WVYKA Z WAGROWCA, THEOLOGA SOCIETATIS IESV. Z DOZWOLENIEM STOLICE APOSTOLSKIEY, a naktadem Iego M. Kśiędza Arcybiskupa Gnieźnieńskiego, etć. wydane, Kraków: Druk. Łazarzowa, nakł. S. Karnkowski, 1599, 2, BUWr, sygn. 437771, BO, sygn. XVI.F.4289

D. Bieńkowska, Jak Jakub Wujek Pismo Święte na język polski przektadat (O warsztacie ttumacza i technice przez niego stosowanej), „Bobolanum”, 9, 1998

Disputationes Roberti Bellarmini Politiani, Societatis Iesv, De Controversiis Christianae Fidei, Adversus huius temporis Haereticos: Tribus Tomis comprehensae. Primi Tomi. Tertia Controversia Generalis, De Summo Pontifice, Ingolstadii: Sartorius, 1587

D. Frick, Anglo-Polonica. The Rheims New Testament of 1582 and the Making of the Polish Catholic Bible, „The Polish Review”, 36, 1991

D. Frick, Polish Sacred Philology in the Reformation and the Counter-Reformation (Chapters in the History of the Controversies 1551-1632), Berkeley-Los Angeles-London 1989

J. Gołąb, O ttumaczeniu Nowego Testamentu przez Jakóba Wujka, Warszawa 1906

D. Kuźmina, Pod sztandarem stowa, Warszawa 2004

The NEVV TESTAMENT OF IESVS CHRIST, TRANSLATED FAITHFVLLY INTO ENGLISH out of the authentical Latin, according the best corrected copies of the same, diligently conferred vvith the Greeke and other editions in divers languages: Vvith ARGVMENTS of bookes and chapters, ANNOTATIONS, and other necessarie helpes, for the better vnderstanding $o$ the text, and specially for the discoverie of the CORRVPTIONS of divers late translations, and for cleering the CONTROVERSIES in religion, of these 
daies: IN THE ENGLISH COLLEGE OF RHEMES, Rhemes: I. Fogny, 1582, Princeton Theological Seminary Library, sygn. 3.25.13.40-2/6

P. Nicko-Stępień, Wulgata Lowańska a Nowy Testament $w$ przektadzie ks. Jakuba Wujka z roku 1593. Studium Mt 16, 13-20, OiRwP, 59, 2015, s. 47-66

Nowy Testament Pana naszego IESVSA CHRISTVSA. Z nowu z Laćińskiego y $z$ Gręckiego na Polskie wiernie a szczyrze przetożony: y Argumentami abo Summariuszami każdych Kśiag / y Rozdźiatow / y Annotacyami po brzegach obiaśniony. Przydane sa Nauki y Przestrogi mato nie za kazdym Rozdźiatem: Porownanie Ewangelistow SS. Dźieie y drogi rozmaite Piotra y Pawta S. $y$ Regestr rzeczy gtownieyszych na końcu. Przez D. IAKVBA WVYKA. Theologa Societatis IESV. Z dozwoleniem Starszych. Pod rozsadek Kościota S. Powszechnego Rzymskiego wszytko niech podlęże, Kraków: A. Piotrkowczyk, 1593, $4^{\circ}, \mathrm{BO}$, sygn. XVI.Qu.3065

Nowy Testament Pana naszego IESVSA CHRISTUSA. $Z$ nowu z Lacíńskiego y z Grackiego na Polskie wiernie a szczyrze przetożony. Przez D. IAKVBA WVYKA Theologa Societatis IESV. Z dozwoleniem Starszych. Pod rozsądek Kościota S. Powszechnego Rzymskiego wszytko niech podlęże, Kraków: A. Piotrkowczyk, 1594, $8^{\circ}, \mathrm{BO}$, sygn. XVI.O.665

NOWY TESTAMENT. To iest Wszytkie pisma nowego Przymierza / z Greckiego ięzyka na rzecż Potskq wiernie y szcżerze przetożone. Przydane iest rozne cżytanie na brzegach / ktore się $w$ inszych kśiegach nayduie: y Reiestr na końcu, [Kraków]: A. Rodecki, 1577, 4 , BO, sygn. XVI.Qu.1773

Nowy Testament $w$ przektadzie ks. dr Jakuba Wuika T.J. z roku 1593, red. W. Smereka, Kraków 1966

Nowy Testament znowu przetożony / a na wielu mieyscach za pewnemi dowodami od przysad przez Simona Budnego ocżyściony / i krotkiemi przypiskami po kraioch objaśniony. Przydane też sa na końcu tegoż dostateczniejsze przypiskil które każdey iak miarz odmiany przyczyny ukazuia, Łosk: [Daniel z Łęczycy], nakł. J. Kiszka, 1574, 8, BO, sygn. XVI.O.191

L. Piechnik, Poczatti Akademii Wileńskiej (1570-1599), Rzym 1984

R. Pietkiewicz, Pismo Święte w jezzyku polskim w latach 1518-1638. Sytuacja wyznaniowa $w$ Polsce a rozwój edytorstwa biblijnego, [rozprawa doktorska], Wrocław 2002

J. Sygański, Korespondencja ks. Jakóba Wujka z Wagrówca z lat 1569-1596, „Roczniki Towarzystwa Przyjaciół Nauk Poznańskiego”, 44, 1918

J. Sygański, Korespondencja ks. Jakóba Wujka z Wagrówca z lat 1569-1596, „Roczniki Towarzystwa Przyjaciół Nauk Poznańskiego”, 45, 1918

J. Sygański, Korespondencja ks. Jakóba Wujka z Wagrówca z lat 1569-1596, „Roczniki Towarzystwa Przyjaciół Nauk Poznańskiego”, 46, 1920 


\section{Sources for the Textual Commentary on the New Testament in 1593 Jakub Wujek's Translation. The Study of Acts 2:14-36}

The purpose of the study is to indicate the sources for a textual commentary on the New Testament in Jakub Wujek's translation of 1593. The problem is presented on the example of Act of Apostles, chapter 2, verses 14-36 (Acts 2:14-36). In his translation, Wujek used the two main sources: the English version of the Rheims New Testament of 1582, and Robert Bellarmine's Disputationes Christianae Fidei.

The question of sources for the New Testament in Jakub Wujek's translation has been almost completely unexplored or explored incorrectly. A comparative analysis of Wujek's commentary with that of Bellarmine's and of the Rheims New Testament has led to surprising conclusions: that Jakub Wujek, one of the most outstanding Bible translators in the sixteenth century, probably knew English, and his textual commentary to the New Testament of 1593 is a compilation of the two abovementioned texts (English and Latin). This means that as a Bible commentator Wujek was imitative and dependent on secondary sources, as he did not use texts by Church Fathers, but relied on quotations from their writings he found in other compendia instead.

Paulina Nicko-Stępień, doktorantka teologii biblijnej w Papieskim Wydziale Teologicznym we Wrocławiu oraz orientalistyki w Instytucie Studiów Klasycznych, Sródziemnomorskich i Orientalnych na Uniwersytecie Wrocławskim. Przygotowuje rozprawy doktorskie na temat źródeł dla komentarza Nowego Testamentu w tłumaczeniu Jakuba Wujka (1593) oraz o eschatologii w starożytnej Mezopotamii.

Paulina Nicko-Stępien - PhD student of the Biblical theology at the Pontifical Faculty of Theology, and of Oriental studies at the Institute of Classical, Mediterranean and Oriental Studies of the University of Wrocław. She works on her two doctoral dissertations - one devoted to sources for the New Testament in Jakub Wujek's translation (1593), another on eschatology in ancient Mesopotamia.

E-mail: paulina.nicko-stepien@uwr.edu.pl 